Bayreuth

\title{
Indywidualna skarga konstytucyjna w Polsce i w Niemczech: Jak proceduralne różnice wpływają na pozycję instytucji?
}

\begin{abstract}
Streszczenie: Tendencja do porównywania polskiego sądu konstytucyjnego z jego niemieckim odpowiednikiem prowadzi do powstania złudzenia, że obie instytucje mają nie tylko prawie takie same pozycje ustrojowe, ale również, że procedura przed nimi oraz kompetencje orzecznicze są prawie identyczne, a co za tym idzie pozycja faktyczna obu instytucji powinna być podobna. Referat traktuje o różnicach w postępowaniu w sprawach skarg konstytucyjnych w Polsce i w Niemczech i ich znaczeniu dla faktycznej pozycji obu trybunałów. Wąski model skargi konstytucyjnej w Polsce po $1997 \mathrm{r}$. (w szczególności możliwość skargi jedynie „na przepis” a nie działanie organów państwa), powoduje że TK od początku swego istnienia ma stosunkowo wąski zakres orzekania, podczas gdy jego niemiecki odpowiednik, dzięki szerokiemu dostępowi obywateli do skargi konstytucyjnej, wykształca silne linie orzecznicze $\mathrm{w}$ różnych dziedzinach życia mające moc podobną do precedensów znanych z anglosaskiego systemu prawnego. Jednym więc powodem stosunkowo małego znaczenia TK w Polsce jest wąski dostęp obywateli do skargi konstytucyjnej oraz co za tym idzie mniejsza ilość orzeczeń i niemożliwość wykształcenia się tak różnorodnych linii orzeczniczych jak w Niemczech, ponieważ znaczenie sądu zależy m.in. od ilości wydanych wyroków, czyli unormowanych przez niego spraw.
\end{abstract}

Słowa kluczowe: Trybunał Konstytucyjny, Federalny Trybunał Konstytucyjny, skarga konstytucyjna, postępowanie przed trybunałem konstytucyjnym, prawo konstytucyjne w Niemczech

B odaj najboleśniejszą cechą rządów dyktatorskich dla świadomej jednostki jest brak możliwości osadzonego w prawnych ramach sprzeciwu wobec działań władzy. Pomne tych doświadczeń państwa Europy Środkowej i Wschodniej, wychodząc z okresu rządów autorytarnych pod koniec XX wieku, poszukiwały wzorców ustrojowych gwarantujących nie tylko stabilność rządów, ale i zapewniających możliwość ograniczania władzy i ochrony praw człowieka. Największe nadzieje pokładano w mechanizmach sądowych. Były one co prawda obce socjalistycznej nauce prawa, ale doświadczenia takich krajów, jak Niemcy, Hiszpania i Portugalia, które przejście od dyktatury do demokracji miały już za sobą, potwierdzały ich skuteczność. Dlatego głównie stamtąd czerpano inspiracje dla trybunałów, które miały i tu sprawdzić się w okresie przebudowy, studząc zakusy polityków, którzy wychodząc z roli opozycji, mniej lub bardziej świadomie inspirowali się metodami poprzednio rządzących.

O ile historycznie starsza, bo mająca korzenie jeszcze w XIX w. kontrola działalności administracji publicznej poprzez sądownictwo administracyjne była z perspektywy władzy łatwiejsza do zaakceptowania (sądy te opierają swoje wyroki na ustawach uchwalanych przez najczęściej popierającą rząd większość parlamentarną, a więc nie wchodzą w kompetencje legislatywy), o tyle trudniejszym do zaakceptowania z perspektywy silnie zakorzenionego legicentryzmu było ograniczenie samego parlamentu poprzez instytucję sądu konstytucyjnego - sądu nad prawem, który może „skazywać” ustawy na niebyt, a tym samym podważać zdanie większości parlamentarnej na podstawie przepisów 
wyższego rzędu, jakimi są zapisy w konstytucji. Był to zalążek problemu sądownictwa konstytucyjnego w Europie Środkowej i Wschodniej. Z jednej strony dążono do tworzenia silnego państwa prawa, z drugiej zaś obawiano się zbyt daleko idących konsekwencji oddania „ostatniego słowa” w ręce sędziów konstytucyjnych. Ilustracją tych przeciwstawnych tendencji jest instytucja indywidualnej skargi konstytucyjnej w Polsce.

Jako że celem niniejszego artykułu nie jest ukazywanie wszystkich niuansów proceduralnych między rozpatrywaniem skarg konstytucyjnych w Polsce i w Niemczech, w dalszej części zostaną przedstawione jedynie takie, które wydatnie wpływają na pozycję obu sądów konstytucyjnych, ukazując w jaki sposób procedura kreuje znaczenie sądu i w jakich okolicznościach to sąd może za pomocą procedury tworzyć swoją pozycję.

\section{Geneza instytucji sądu nad prawem}

Z dzisiejszej perspektywy istnienie sądu konstytucyjnego lub innego mechanizmu mogącego podważyć ustawy wydaje się być oczywistym elementem demokratycznego państwa prawnego. Nawet w obecnej napiętej sytuacji wokół Trybunału Konstytucyjnego w Polsce da się zauważyć, że strony sporu postrzegają sąd konstytucyjny jako instytucję nierozerwalnie związaną z państwem prawa, mimo różnic w percepcji tego pojęcia, jako że żadna ze stron nie neguje istnienia tej instytucji jako takiej. Instytucja sądu nad prawem cieszy się zbyt dużym szacunkiem, by móc ją zanegować. W głównej mierze przyczyniły się do tego silne sądy krajowe jak chociażby Sąd Najwyższy USA oraz międzynarodowe, takie jak Europejski Trybunał Sprawiedliwości czy Europejski Trybunał Praw Człowieka, opierające swoje wyroki na prawach człowieka sformułowanych $\mathrm{w}$ różnych aktach prawnych. Jednak w systemie kontynentalnym pierwszym z kolosów sądowej kontroli aktów prawnych był Federalny Trybunał Konstytucyjny Republiki Federalnej Niemiec (FTK) i to on stał się inspiracją dla swych naśladowców szczególnie w Europie Środkowej. Jak to jednak możliwe, że instytucja sądowa wyrosła w drugiej połowie XX w. na czołowy organ konstytucyjny RFN, inspirując prawników do nazywania powojennych Niemiec Republiką Sędziów (Richterrepublik)?

\subsection{Sytuacja w Niemczech}

Koncepcja sądu konstytucyjnego jest dziełem niemiecko-austriackiej tradycji konstytucyjnej. Pierwszy w Europie sąd konstytucyjny powstał w Austrii w 1920 r., następny w Czechosłowacji rok później. Instytucje te nie obroniły się jednak w czasach rosnących w siłę tendencji autorytarnych, których inspiratorem i naukowym patronem stał się Carl Schmitt, upatrujący w głowie państwa strażnika konstytucji, odwrotnie do swojego adwersarza w sporach zwanych „Methodenstreit der Weimarer Republik” Hansa Kelsena, który w ciele sądowniczym, niezależnym od legislatywy i egzekutywy widział gwarancję zgodności ustaw z konstytucją i jej strażnika. Lata totalitaryzmu hitlerowskiego przyczyniły się do starcia z powierzchni ziemi sądów konstytucyjnych w ówczesnych formach. Paradoksalnie jednak przyczyniły się także do triumfalnego odrodzenia się tej instytucji po 1945 roku. Jak Feniks z popiołów powstała wtedy nowa generacja sądów 
konstytucyjnych z wiodącym prym wśród nich - nie tylko ze względu na swoje starszeństwo wiekiem - Federalnym Sądem Konstytucyjnym RFN.

Rozwinięty po II wojnie światowej model sądownictwa konstytucyjnego opierający się na Kelsenowskim modelu hierarchii norm prawnych rozpowszechnił instytucję „sądu nad prawem”, który miał za zadanie strzec zgodności norm niższego rzędu z normami wyższego rzędu. Na szczycie hierarchii przewidywał on normy konstytucyjne, w szczególności prawa człowieka inspirowane prawem natury czy też prawa podstawowe. Sąd konstytucyjny miał być bowiem przeciwwagą wobec skompromitowanego po doświadczeniach narodowego socjalizmu, cytując Gustawa Radbrucha, „ustawowego bezprawia" (Radbruch, 1946, s. 108), czyli legicentrycznego (Izdebski, 2016, s. 5 i n.) pojmowania roli parlamentu i pozytywistycznego uznawania za prawo także tych aktów woli władzy, które choć wydawane przez organy posiadające demokratyczną legitymację były rażąco bezprawne czy wręcz okrutne i sadystyczne.

W 1951 roku, gdy Federalny Trybunał Konstytucyjny Niemiec podejmował działalność orzecznicza, panowała wyjątkowo korzystna koniunktura dla tego typu instytucji. Po pierwsze, zakorzeniona w Niemczech jeszcze od czasów Republiki Weimarskiej nieufność wobec instytucji parlamentu, wzmocniona porażką legicentryzmu i pozytywizmu prawniczego dała potwierdzenie przeświadczeniu, że ani kolegialnie działająca, demokratycznie wybrana legislatywa, ani silna egzekutywa nie są w stanie samoistnie bronić nowego demokratyczno-wolnościowego porządku prawnego (freiheitlich demokratische Rechtsordnung). Potrzebny był zatem strażnik tyleż silny co przewidywalny i osadzony w ramach, których sam nie może zmieniać. Tymi ramami stały się prawa podstawowe (Grundrechte), zainspirowane rozpoczynającymi swój powojenny renesans prawami człowieka, zabezpieczone przez „Ewigkeitsklausel” - klauzulę uniemożliwiającą ich zmianę przez legislatywę. Strażnikiem natomiast miała stać się instytucja sądownicza, a więc działająca na wniosek, a nie z własnej inicjatywy i powoływana w porozumieniu władzy wykonawczej z ustawodawcza. Strażnik ten miał jedynie reagować na naruszenia praw podstawowych, zostawiając autonomię ustawodawcy w dziedzinie tworzenia prawa, a instytucjom egzekutywy w ramach jego wykonywania. Postanowiono jednak, że będzie on na tyle silny, by mógł mieć ostatnie, niepodważalne słowo w kwestiach, które miał badać na podstawie swojej wykładni praw podstawowych. Tak można by streścić zamiary przyświecające „matkom i ojcom ustawy zasadniczej” (Mutter und Väter des Grundgesetzes) czyli członkom komisji ustawodawczej, która uchwaliła do dziś obowiązującą Ustawę Zasadniczą RFN w 1949 r.

Gdy w 1951 r., za rząáów cieszącego się niekwestionowanym autorytetem Konrada Adenauera, podejmował działalność FTK, nie spodziewano się jaką odegra rolę w historii światowego sądownictwa. Już w 1981 r. Ernst-Wolfgang Böckenförde, późniejszy sędzia FTK oraz cieszący się wielkim poważaniem profesor prawa, nie bezkrytycznie pisał o przejściu od parlamentarnego modelu stanowienia prawa do sądowego za sprawą FTK (Böckenförde, 1981, s. 402). Przez pierwszych trzydzieści lat swojej działalności trybunał wychodził niejednokrotnie zwycięsko z potyczek z większością parlamentarną i okazał się instytucją samodzielną i nieugiętą. Wspierały go w tym inne najwyższe instytucje sądownicze: w 1959 r. prezes Federalnego Trybunału Administracyjnego Fritz Werner uznał prawo administracyjne za skonkretyzowane prawo konstytucyjne, a tym samym symbolicznie uznał wyższość sądu konstytucyjnego nad swoją instytucją (Werner, 1959, s. 527 
i n.). FTK wysuwał się przez lata na czoło organów państwowych i uznawany był także jako sąd, a nie tylko za najwyższy organ konstytucyjny państwa. Nie chodziło przy tym wyłącznie o ostateczność orzeczeń trybunału (zapisaną w § 31 BVerfGG), ale o symboliczne ostatnie słowo, o to że żaden inny organ konstytucyjny nie ważył się deprecjonować jego roli jako ostatecznego, wiążącego interpretatora konstytucji.

Posłuch dla FTK umacniał się, napotykając jednocześnie opór w środowiskach naukowych (Jestaedt, Lepsius, Möllers, Schönberger, 2011), lecz nigdy zdecydowanych działań rządzących. Wręcz przeciwnie, w sporze między najwyższymi sądami RFN o pytania prawne i sugerowanie odpowiedzi przez nie FTK (Gutachten-Streit) to właśnie ustawodawca zabronił tej praktyki, wzmacniając tym samym pozycję swego, jakby się wydawało, adwersarza. Swą silną pozycję wykorzystywał i wykorzystuje FTK, wciąż niejednokrotnie przekraczając swoje uprawnienia wynikające $\mathrm{z}$ koncepcji ustawodawcy negatywnego - jedynie usuwającego niezgodne normy prawne - oraz z przepisów konstytucji, tworząc za pomocą tzw. wykładni przyjaznej konstytucji (verfassungsfreundliche Auslegung) w swych wyrokach zestaw wiążących wymagań wobec ustawodawcy w stosunku do przepisów prawnych. Taka sytuacja miała miejsce, gdy FTK w ponad stustronicowym wyroku dot. inwigilacji w procesie karnym (Großer Lauschangriff) praktycznie sformułował swoje brzmienie przepisów, które parlament miał jedynie przegłosować, co też się stało, pomimo dwóch zdań odrębnych sędziów oraz zmasowanym protestom nauki prawa. Politycy jednak milczeli i postąpili zgodnie z wytycznymi „najwyższego organu konstytucyjnego”.

Pozycja faktyczna FTK w ramach systemu organów państwa jest szeroko dyskutowana w Niemczech - powiedzieć, że budzi liczne kontrowersje to za mało. Ma to jednak miejsce jedynie $\mathrm{z}$ jednej strony na poziomie naukowym, a $\mathrm{z}$ drugiej na poziomie politycznego folkloru. Rola jaką odegrał FTK w prawie siedmiu dekadach swego istnienia dla rozwoju praw podstawowych i zasad prawa konstytucyjnego, nie tylko w Niemczech ale i na świecie, jest na tyle ogromna i pozytywna, że żaden racjonalnie działający polityk nie kwestionuje jego roli w systemie politycznym. Prawdopodobnie jakakolwiek agresywna, niemerytoryczna krytyka FTK odebrałaby powagę i wiarygodność czyniącemu ją politykowi. Trybunał posiada szeroką autonomię budżetową $i$ autonomię proceduralną, mówi się o nierozerwalnym sprzężeniu trybunału z niemiecką ustawą zasadnicză, a poważnie myślący sceptycy poszukują możliwości przezwyciężenia monopolu FTK na rozstrzyganie sporów konstytucyjnych w sądach międzynarodowych. Na każdy fenomen zbiera się jednak kilka czynników. Oczywiście był to czas, w którym powstał FTK otwierający drogę do odważnych orzeczeń oraz powojenny renesans praw człowieka i nieufność wobec legislatywy i egzekutywy, jednak również sama procedura przed FTK umożliwiła mu zabieranie głosu w licznych sprawach. Najbardziej efektywnym, ale i społecznie efektownym postępowaniem pod tym względem jest indywidualna skarga konstytucyjna, czyli instytucja umożliwiająca w niemieckich warunkach każdemu obywatelowi przedstawić swoje racje przed „najwyższym organem konstytucyjnym”.

\subsection{Sytuacja w Polsce}

Pozornie tylko sytuacja, w której powstawał polski Trybunał Konstytucyjny wydaje się być podobna. Wydawałoby się, że oto, gdy autorytaryzm okazuje się drogą donikąd, 
władza pozwala instytucji sądowniczej na kontrolę nad sobą. Łatwiej jest jednak znaleźć różnice niż podobieństwa sytuacji prawno-konstytucyjnej Polski lat 80-tych i Niemiec końca lat 40-tych i początku lat 50-tych.

Przede wszystkim, powstanie TK związane jest nie tyle z absolutną klęską dotychczas panującej ideologii, jak miało to miejsce $\mathrm{z}$ nazizmem po wojnie, ile wiąże się ze stopniowym słabnięciem rządów autorytarnych w Polsce, a jako takie było możliwe jedynie w drodze kompromisu. Instytucja sądu konstytucyjnego była obca socjalistycznej nauce prawa skoncentrowanej na centralnej roli parlamentu, który składając się z przedstawicieli ludu pracującego miast i wsi miał sprawować w jego imieniu niepodzielną władzę w państwie. Niepodzielną w aspekcie trójpodziału władz, który był zachwiany i w aspekcie przekazywania władzy, ponieważ była ona zarezerwowana dla PZPR pełniącej kierowniczą rolę. Koncepcja jedności władzy państwowej, odrzucająca trójpodział władzy oraz jego limitujące skutki dla rządzących sprzeciwiała się idei sądu konstytucyjnego. Jurysprudencja socjalistyczna nie przywiązywała wagi do kontroli konstytucyjności ustaw, nazywając ją reakcyjną i charakterystyczną dla państw burżuazyjnych. Była to naleciałość, której w socjalizmie pragnięto się pozbyć (Rozmaryn, 1948, s. 20). Mimo to, w latach 80-tych udało się przeprowadzić liczne reformy sądownictwa w duchu przeciwnym do socjalistycznej nauki prawa, mające, jak się okazało, duży wpływ na postępujące zmiany ustrojowe. Jako pierwszą wprowadzono w 1980 r. kontrolę działalności administracji poprzez Naczelny Sąd Administracyjny, jakkolwiek w ograniczonym zakresie. Jednak dopiero powołanie do życia Trybunału Konstytucyjnego w 1985 r. stanowiło swoisty przełom. Od tego momentu przed parlamentem wyrósł przeciwnik mogący kwestionować akty prawa powszechnie obowiązującego na podstawie ich niezgodności z nadrzędnymi normami konstytucji. Na zewnątrz, szczególnie dla zagranicy miało to uchodzić za wspaniałomyślny gest, gdyż oto dotąd niczym nielimitowany parlament kontrolowany przez jedną partię postanowił sam siebie ograniczyć. Oczywistym jednak było, że taka decyzja miała swoją cenę.

Przeciwnik, którego Sejm sam sobie stworzył był jednak słaby, by nie stał się mocą swojego autorytetu graczem na scenie politycznej, czego z resztą sam próbował uniknąć - w skład pierwszego TK weszli głównie umiarkowani naukowcy i sędziowie, którzy ze swej natury nie byli rewolucyjnie nastawieni. Nie znaczy to jednak, że TK był uległy wobec władzy, zachowywał jednak chłodny obiektywny dystans, wykorzystując te narzędzia, które otrzymał na tyle, na ile mógł (Garlicki, 1990, s. 289). W tamtym okresie chodziło głównie o to, by dać wyraz dobrej woli wdrażania reform ustrojowych, wysłać sygnał za granicę, że władza w Polsce jest skłonna układać się z opozycją i chce iść drogą reform. TK powstał jako instytucja kompromisowa, a więc taka, której działalność obwarowana jest licznymi ograniczeniami. Od samego początku działalności orzeczniczej TK w przeciwieństwie do swojego niemieckiego, starszego odpowiednika borykał się nie tylko z naturalnym problemem budowania swojej faktycznej pozycji między organami państwa, ale również z ograniczeniami znaczenia jego orzeczeń wynikającymi z samej ustawy o TK. Za największą przeszkodę dla wybicia się Trybunału należy uznać możliwość obalenia jego wyroków większością 2/3 głosów przez Sejm oraz ograniczona kognicja TK, a także możliwość inicjowania postępowań jedynie przez wyznaczone organy. Sprawiało to, że po wydaniu orzeczenia o niekonstytucyjności przepisu pozostawało ono niejako w próżni prawnej i dopiero głosowanie Sejmu nadawało mu walor 
niepodważalności. Sejm mógł więc korzystać ze swego uprawnienia i przekładać głosowania nad niewygodnymi orzeczeniami, w ten sposób utrudniając ich wykonalność i pokazując, że to on a nie Trybunał ma ostatnie słowo.

Przełomowe lata 1989 oraz 1990 nie przyniosły sądownictwu konstytucyjnemu w Polsce ani tego co spowodowały w gospodarce, ani też pożądanego wiatru w żagle. Choć w sąsiednich krajach wzorowano się na doświadczeniach Polski i powoływano do życia sądy konstytucyjne, w naszym kraju jego sprawa zeszła na dalszy plan, w obliczu pilniejszych przekształceń gospodarczych i politycznych. Stan sądownictwa w Polsce jako takiego nie był zły, w porównaniu z innymi krajami socjalistycznymi. Polska miała system sądowej kontroli administracji, miała Rzecznika Praw Obywatelskich, gwarancje niezawisłości sędziów oraz funkcjonujący sąd konstytucyjny. Podczas gdy pozostałe kraje bloku wschodniego musiały dopiero tworzyć takie standardy, w Polsce można było przystapić do ich rozwoju. Paradoksalnie ustrojodawca po 1989 roku utrzymywał podobny kurs względem sądu konstytucyjnego do swojego socjalistycznego poprzednika, ponieważ najwyraźniej nie widział interesu w umacnianiu pozycji TK i dążeniu do tworzenia „Republiki Sędziów” na wzór niemiecki. Aż do 1997 roku nie zdecydowano się wprowadzić instytucji indywidualnej skargi konstytucyjnej, nie uregulowano kwestii stanowczości wiązania wytycznych TK zawartych w wyrokach w stosunku do ustawodawcy, nie pochylono się też nad kwestią skutków orzeczeń w zadowalającym stopniu, nie mówiąc już o uniezależnianiu TK od parlamentu pod względem finansowym czy proceduralnym.

Konstytucja z 1997 roku także nie przyniosła w tym względzie przełomu. Owszem, jej art. 188 wymienia doniosłe kompetencje ustawodawcy negatywnego, jednak koncepcja umacniania pozycji przez poszerzanie uprawnień tej instytucji nigdy nie cieszyła się popularnością u polityków niezależnie od przynależności partyjnej. Parafrazując słowa prof. Ewy Łętowskiej upatrywali oni w Trybunale grono złośliwych prawników obalających ich jakoby „własne” ustawy (Łętowska, 2012, s. 267). To nastawienie obrazuje niewykonywanie wyroków TK, na co uskarżali się sędziowie chociażby w 2011 roku. Przykładowo, postanowienie sygnalizacyjne w sprawie pracy operacyjnej organów ścigania z 25 stycznia 2006 r. do dziś nie spotkało się z jakąkolwiek reakcją ustawodawcy, który wydaje się go ignorować.

Z powyższego opisu nie należy wysuwać pochopnego wniosku, że TK nie sprawdził się w swej roli. Zrobił to nawet $\mathrm{z}$ nawiązka, niejednokrotnie odważnie limitując zakusy rządzących jak w przypadku lustracji czy kompetencji Centralnego Biura Antykorupcyjnego albo wstawiając się za tymczasowo aresztowanymi. Wydaje się, że polskiemu sądowi konstytucyjnemu zabrakło jednak z jednej strony swoistej odwagi neofity, jaką dysponował FTK zaskakując rządzących swoimi decyzjami i wymuszając na nich działania zgodne ze swoją interpretacją konstytucji. Z drugiej zaś samo prawo zarówno proceduralne, jak i materialne uniemożliwiało mu to na większą skalę. Trafnie zauważa Adam Sulikowski sugerując, że TK wpada we własną pułapkę neutralności, ponieważ podejmuje z natury rzeczy polityczne (nie w rozumieniu polityki partyjnej, ale w rozumieniu kierunku rządzenia), nieneutralne orzeczenia, ale zawsze uznaje się jedynie za sąd, dla którego poglądy nie grają większej roli, ponieważ liczy się interpretacja ustaw, za którą zawsze można się skryć (Sulikowski, 2016, s. 13). Widać tu wyraźną kontrę do poglądów FTK o samym sobie: polski TK widzi siebie jako sąd, ale już nie „najwyż- 
szy organ konstytucyjny państwa”. Ponownie, zarówno uwarunkowania historyczne, jak i proceduralne miały wpływ na (samo)pojmowanie TK. Przykład indywidualnej skargi konstytucyjnej pokazuje jednak, jak bardzo związane ręce miał polski sąd konstytucyjny w budowaniu silnej pozycji.

\section{Konstrukcja indywidualnej skargi konstytucyjnej wyznacznikiem znaczenia sądu konstytucyjnego}

Wprowadzenie w 1997 roku indywidualnej skargi konstytucyjnej, która w Niemczech nie tylko znacząco przyczyniła się do zwiększenia znaczenia FTK, ale i doprowadziła de facto do zwiększenia kognicji (Lepsius, 2015, s. 127) niemieckiego trybunału, nie miało aż takiego wpływu na pozycję sądu konstytucyjnego w Polsce. $Z$ jednej strony, biorąc pod uwagę ukształtowanie normatywne procedury przed TK wydaje się, że nie mógł on podążać śladami swego odpowiednika z Niemiec, z drugiej zaś strony najwyraźniej nie chciał też umacniać swojego znaczenia, starając się balansować między twórczą interpretacją zasad prawa, a jednoczesnym odcięciem się od kreowania nowych praw podstawowych wzorem niemieckiego FTK. Poza tym sformalizowana droga utrudniająca obywatelowi wnoszenie skarg na naruszenie swoich praw przed TK powodowała, że sąd konstytucyjny pozostał dla niego odległy, mimo formalnej możliwości składania skargi konstytucyjnej.

Jako instytucja niedysponująca żadną fizyczną siłą przeforsowywania swych racji, a jedynie osadzona przez władzę ustawodawczą i wykonawczą z własnej woli, aby limitować jej, jak pamiętano, niejednokrotnie barbarzyńskie zapędy, FTK został wyposażony w zaskakująco szerokie prerogatywy. Najważniejszą z nich wydaje się być z perspektywy czasu rozstrzyganie indywidualnych skarg konstytucyjnych, które w niemieckich warunkach ukształtowało się w specyficzny sposób i daje obywatelowi bezpośrednie, stosunkowo łatwo dostępne narzędzie skontrolowania działania państwa odbijającego się na jego prawach podstawowych.

Twórcy niemieckiej Ustawy Zasadniczej (GG) nie zdecydowali się jednak na wprowadzenie skargi konstytucyjnej w pierwotnym tekście z 1949 roku, jednak dwa lata później w ustawie o FTK zawarto tę instytucję, by w 1969 r. po znowelizowaniu GG wprowadzić ją na poziom konstytucyjny, co świadczyło o tym, że na przestrzeni 20 lat skarga konstytucyjna okazała się narzędziem ważnym i na tyle potrzebnym, by umieścić ją w akcie ponadustawowym, uniemożliwiając w ten sposób łatwą zmianę jej podstaw.

Wprowadzenie indywidualnej skargi konstytucyjnej do polskiego systemu naznaczone było licznymi zastrzeżeniami i obawami. Przede wszystkim obawiano się napięć związanych z kompetencjami do ostatecznego rozstrzygania indywidualnych spraw sądowych z Sądem Najwyższym, o czym niżej. Poza tym, poznawszy zapał Polaków do artykułowania bardziej lub miej zasadnych skarg na własny los po utworzeniu instytucji Rzecznika Praw Obywatelskich w 1987 r., kiedy to w pierwszym okresie działalności urząd liczący zaledwie kilkanaście osób zasypany został w ciagu roku ponad 50000 pismami (Biuletyn RPO z 1988 r., nr 2), z których wiele okazało się być wynurzeniami pieniaczy (Łętowska, 1992, s. 5) postanowiono starać się uniknąć tej samej niepoważnej sytuacji w TK, dlatego też polska skarga konstytucyjna jest środkiem wysoce sformalizowanym. 


\subsection{Szeroka koncepcja skargi}

W Niemczech indywidualna skarga konstytucyjna, której zrąb zawiera art. 93 ust. 4a GG, a która została szerzej uregulowana w $§ 90$ ust. 1 BVerfGG ma kilka ważnych cech charakterystycznych, odróżniających ją od skargi konstytucyjnej w Polsce, a co za tym idzie, przyczyniających się do utwierdzania silnej pozycji ustrojowej FTK.

Niemcy zdecydowały się przyjąć szeroki model skargi konstytucyjnej (Derlatka, 2009, s. 288), według którego każdy, czyje prawa podstawowe zostały naruszone przez władzę publiczną, może złożyć skargę do FTK. Naruszenie praw podstawowych przez władzę publiczną interpretowane jest tu szeroko jako jakiekolwiek działanie czy też zaniechanie władzy ustawodawczej, wykonawczej lub sądowniczej (Kingreen, Poscher, s. 311). Jest to odmienna koncepcja skargi konstytucyjnej od znanej z polskiego systemu, w którym skarga dopuszczalna jest jedynie na przepis, na podstawie którego organ władzy ostatecznie rozstrzygnął naruszając prawa podstawowe obywatela (art. 79 ust. 1 Konstytucji). Fakt ten ma ogromne/przełomowe znaczenie, po pierwsze dla ilości skarg konstytucyjnych w Niemczech (np. w roku 2015 było to 5739 skarg, podobne liczby utrzymują się od lat), jak i dla możliwości oceniania materialnie nieograniczonego spektrum działania władzy państwowej, zarówno na poziomie krajów związkowych, jak i na poziomie federalnym.

Konsekwencją przyjęcia szerokiej koncepcji skargi jest nie tylko duża ilość wpływów. Dużo ważniejszą z punktu widzenia postrzegania instytucji w społeczeństwie jest wytworzenie uczucia, że każdy może zwrócić się do sądu, a zarazem najwyższego organu konstytucyjnego ze swoją sprawą. Dzięki temu tzw. zwykły obywatel wie, w jakim celu istnieje sąd konstytucyjny i wie, że może obdarzyć go zaufaniem. Sąd zyskuje natomiast to co dla instytucji tego typu kluczowe - sprawy do orzekania, a inaczej rzecz ujmując, społecznie ważkie tematy, co do których może zabrać głos, i to na wezwanie obywatela. Ma to inny wydźwięk, także wizerunkowy, niż wyrok wydany z inicjatywy organu państwa, jak ma to miejsce w procedurze abstrakcyjnej kontroli norm prawnych, jakkolwiek ważnej szczególnie w Polsce.

\subsection{Subsydiarność skargi}

Zarówno polska, jak i niemiecka koncepcja skargi konstytucyjnej zakłada konieczność wyczerpania drogi prawnej zanim dojdzie do jej złożenia, czyniąc z niej warunek dopuszczalności skargi (art. 47 ust. 1 TKU z 2016 r. wcześniej art. 46 ust. 1 TKU z 1997 r. oraz $§ 90$ ust. 2 zd. 1 BVerfGG). Jednakże niemieckie przepisy otwierają drogę FTK do orzekania, gdy ten uzna, że mimo braku spełnienia przesłanki wyczerpania drogi odwoławczej (przesłanki subsydiarności), sprawa przedstawiona trybunałowi ma znaczenie dla ogółu społeczeństwa lub gdy skarżącemu groziłoby powstanie znacznego, nieodwracalnego naruszenia praw, jeśli swą sprawę skierowałby najpierw na zwykłe tory odwoławcze.

Polski trybunał może jedynie po wpływie skargi wydać postanowienie tymczasowe o zawieszeniu lub wstrzymaniu wykonania orzeczenia w sprawie, której skarga dotyczy, jeżeli wykonanie wyroku, decyzji lub innego rozstrzygnięcia mogłoby spowodować 
skutki nieodwracalne dla skarżącego albo gdy przemawia za tym ważny interes skarżącego lub ważny interes publiczny (art. 51 ust. 1 TKU z 2016 r. wcześniej art. 50 ust. 1 TKU z 1997 r.). Z perspektywy skarżącego taka możliwość chroni go jednak tylko przed skutkami ostatecznego wyroku, który zapada po wielomiesięcznych lub nawet wieloletnich, kosztownych postępowaniach, podczas których jego prawa pozostają naruszane i dopiero po tym czasie daje mu możliwość zwrócenia się do TK ze skargą. Natomiast z perspektywy samego sądu konstytucyjnego pozwala mu to dopiero orzekać, gdy wpłynie skarga, a następuje to po długim czasie od naruszenia, kiedy jego ewentualna negatywna recenzja działania państwa nie jest już tak aktualna, a dla władzy tak bolesna. $\mathrm{Na}$ marginesie można stwierdzić, że FTK przysługuje obok wcześniej wymienionej także powyższa możliwość.

Tak więc postrzegając polski model skargi konstytucyjnej przez pryzmat niemieckich rozwiązań można stwierdzić, że zawęża on TK możliwość nie tylko skutecznej ochrony praw podstawowych, ale również skutecznego zabierania głosu w sprawach aktualnych dla obywateli. Pozornie tylko procedura abstrakcyjnej kontroli norm rozwiązuje ten problem. Dotychczas wydawała się ona bardziej bezpośrednia, a zatem szybsza od skargi konstytucyjnej, choć obecnie, pod rządami nowej ustawy o TK z 2016 r. o rozstrzyganiu decyduje kolejność wpływu wniosków. Trzeba jednak zauważyć, że jakkolwiek stosunkowo obszerne jest orzecznictwo TK w zakresie kontroli abstrakcyjnej ${ }^{1}$, to podmioty mogące ją zainicjować nie zawsze mają w tym interes lub nie zawsze dysponują wystarczającym potencjałem organizacyjnym, aby zajmować się wszystkimi naruszeniami. Dla odmiany w Niemczech tworzą się często inicjatywy społeczne dla zbierania podpisów pod skargami konstytucyjnymi. Jedną z zasługujących na wzmiankę, która poprzedziła wyrok dot. ochrony danych osobowych do dziś znaczący dla europejskich rozwiązań w tej materii, miała miejsce w 1983 r. i zgromadziła kilka tysięcy sygnatariuszy (Volkszählungsurteil).

\subsection{Rozumienie bezpośredniości naruszenia praw podstawowych}

Zasady wnoszenia skargi konstytucyjnej wymagają ponadto, by wykazać jakie konstytucyjne prawa i wolności zostały naruszone i w jaki sposób. W wyroku z 15.10.2002 r. (SK 6/02) TK orzekł, że skarżący musi wykazać związek przyczynowo-skutkowy między zastosowaniem, w jego mniemaniu, sprzecznego z konstytucją przepisu przy ostatecznej decyzji organu publicznego a naruszeniem jego prawa i wolności. Naruszenie to musi być, jak wykazuje się w doktrynie prawa konstytucyjnego, bezpośrednie i osobiste, co uniemożliwia skarżenie naruszeń domniemanych (Małajny, 2013, § 41 pkt 3). Taka regulacja stanowi kolejną zaporę przed pieniactwem procesowym i wnoszeniem skarg jedynie dla przedłużenia postępowania. O ile ten cel można pozytywnie ocenić, to ma on pewien skutek uboczny. Powoduje on mianowicie, że przez „filtr bezpośredniości” nie przedostają się skargi o wysokiej politycznej relewantności, w których niemożliwe jest bezpośrednie i osobiste wykazanie naruszenia, gdyż obywatel nawet może o nim

${ }^{1}$ W roku 2014 odnotowano 75 wpływów, a 37 spraw zakończyło się wyrokiem, podczas gdy w tym samym okresie wpłynęło 375 skarg konstytucyjnych, z czego 44 zostały merytorycznie rozpoznane, a w 22 przypadkach wydano wyrok. Źródło: https://trybunal.gov.pl/fileadmin/content/dokumenty/ds.pdf. 
nie wiedzieć lub jedynie je domniemywać, gdyby akt normatywny wszedł w życie. Taka sytuacja ma miejsce przykładowo przy stosowaniu tajnych operacyjnych podsłuchów przez Policję i inne służby. Obywatel, nie może się na nie bezpośrednio skarżyć, ponieważ nie może wydobyć od organów państwa informacji o fakcie zastosowania podsłuchu bądź jego braku w stosunku do niego. W Niemczech natomiast przesłanka bezpośredniości musi ulec wspomnianej przesłance interesu społecznego. W ten sposób w formie skargi konstytucyjnej obywatel ma możliwość niejako złożenia wniosku o abstrakcyjną kontrolę aktu normatywnego. Sprawia to, że w kluczowych sprawach także dotyczących polityki zagranicznej, jak ,ratowanie Strefy Euro” może wymusić kontrolę aktu normatywnego, wykazując możliwość powszechnego naruszenia praw zawartych w konstytucji (OMT-Urteil, orzeczenie w sprawie Outright Monetary Transactions, wyrok w sprawie zgodności z konstytucją Traktatu z Lizbony czy wyrok w sprawie retencji danych - Vorratsdatenspeicherungsurteil). Oczywiście FTK skwapliwie korzysta z możliwości przyjmowania do orzekania takich skarg, ponieważ pozwala mu to na zabieranie głosu w kluczowych dla państwa sprawach. Tym samym jako instytucja sądownicza, czyli działająca jedynie na wniosek ,zasysa” wszystkie palące sprawy i dokonuje niejako wyboru, które rozstrzygnąć. Wnioskodawców nie brakuje, jako że każdy obywatel może złożyć skargę konstytucyjną. Oczywiście by tego dokonać skarżący musi dysponować odpowiednim zapleczem, dlatego środek ten wykorzystywany jest szczególnie często przez polityków opozycyjnych oraz przez przedstawicieli nauki.

\subsection{Skutki wyroków}

Ten obszerny aspekt zostanie w tym miejscu jedynie potraktowany w powierzchowny sposób, wystarczający do uwypuklenia znaczenia proceduralnych niuansów, dla zwiększania znaczenia instytucji sądu konstytucyjnego. Zarówno wyroki polskiego, jak i niemieckiego trybunału cieszą się przymiotem ostateczności. Jednak ponadto FTK ma możliwość podejmowania zastępczych regulacji, $\mathrm{w}$ razie gdy ustawodawca nie podejmie określonych w wyroku działań i nie zmieni zakwestionowanego przepisu (Btitz, 2015, s. 320). Choć FTK nie korzystał nigdy z tego uprawnienia, zapewnia mu to niewatpliwie „ostatnie słowo" w sporach konstytucyjnych i faktycznie plasuje jako centralny organ konstytucyjny.

Pomimo przymiotu ostateczności wyroków polskiego TK, sędziowie praktycznie od początku istnienia tej instytucji ubolewali nad brakiem woli polityków w stosowaniu postanowień trybunału przy tworzeniu regulacji po wyeliminowaniu wcześniejszych przez sąd konstytucyjny. Sprzyja temu zasada, że jedynie sentencja wyroku jest wiążąca, a nie jego uzasadnienie. Władza ustawodawcza niejednokrotnie bezlitośnie wykorzystywała to, aby nie transponować niewygodnych dla siebie rozstrzygnięć - ostatnio taka sytuacja miała miejsce przy uchwalaniu nowelizacji ustawy o policji (tzw. ustawy inwigilacyjnej) w 2016 r., kiedy to wyeliminowano co prawda przepisy uznane przez trybunał za niezgodne z konstytucją, ale nie stosując się do uzasadnienia wyroku lub traktując je wybiórczo. Takie działania władzy ustawodawczej legitymują częściowo także poglądy doktryny prawa. Jak przytacza A. Mączyński „TK ma służyć eliminacji z systemu prawnego przepisów niezgodnych z Konstytucją, a nie rozstrzyganiu problemów teoretycznych" (Mączyński, 2010, s. 95). 


\section{Podsumowanie}

Przytoczone przykłady nie wyczerpują tematu, pozostają jednak ważnymi ilustracjami problemu, na który niniejszy artykuł ma zwracać uwagę. Otóż, siłą instytucji nie jest jej szumna nazwa, a kompetencje i realna możliwość działania. FTK pojawił się na kartach historii w bardzo korzystnym momencie, gdy to właśnie sądownictwu postanowiono oddać palmę pierwszeństwa straży nad konstytucją. Polski TK natomiast był owocem kompromisu, który już w godzinie jego narodzin z założenia ograniczył jego możliwość wybicia się na pierwszy plan spośród pozostałych władz. Związane było to z licznymi przeciwnościami napotykanymi przez TK w całej swojej dotychczasowej historii. Można do nich zaliczyć pewną wrodzoną niechęć polskich polityków niezależnie od opcji do umożliwiania recenzowania swoich działań, tym bardziej jeśli za negatywną oceną może iść realne działanie wkraczające w kompetencje parlamentu. Poza tym proceduralne odizolowanie trybunału od społeczeństwa, spowodowane wąskim rozumieniem skargi konstytucyjnej, która w polskich warunkach daleka jest o niemieckiej koncepcji zbliżonej do actio popularis powoduje, że trybunał nie ma możliwości zyskania szerokiego poparcia społecznego i zaplecza dla swoich niewątpliwie politycznych, jednak nie w rozumieniu polityki partyjnej, decyzji. O ile przy tworzeniu tej koncepcji przyświecał ustawodawcy być może słuszny zamiar niedopuszczenia do zasypania trybunału sprawami błahymi, o tyle w konsekwencji cena tego rozwiązania okazuje się dość wysoka. Wydaje się, że lepszym rozwiązaniem dla swobód obywatelskich jest umożliwienie wzorem niemieckim, choćby nieuzasadnionego „wyżalenia się” obywatela przed trybunałem i otrzymania odpowiedzi nawet odrzucającej skargę, niż formalnie uzasadnione ograniczenie dostępu do niego generalnie.

Konsekwencją przyjęcia niemieckiej koncepcji skargi konstytucyjnej, a co za tym idzie koncepcji sądu konstytucyjnego jest niewątpliwie „wyjście z ram konstytucji” tegoż organu. Jest ono tyleż kontrowersyjne ile pożyteczne, na co wskazują doświadczenia ochrony praw podstawowych w Niemczech, gdzie to właśnie trybunał jest strażnikiem nie tylko samej konstytucji, ale i praw obywatelskich, co zapewnia mu szerokie poparcie społeczne. Również poważne traktowanie wyroków przez klasę polityczną niewątpliwie pozytywnie odbija się na znaczeniu instytucji sądu konstytucyjnego. Obecna pozycja FTK nie została mu przyznana przez polityków bezpośrednio, lecz była wykuwana podczas licznych przesileń na linii parlament-trybunał, z których jednak ten ostatni wychodził zawsze zwycięsko (Kruzifixurteil). Miał jednak szczęście orzekać w kraju, w którym parlament wciąż nosi skazę czasów, w których tworzył prawo nie tylko niesłuszne, ale i nieludzkie.

\section{Bibliografia}

„Biuletyn Rzecznika Praw Obywatelskich” (1988) nr 2.

Böckenförde E.-W. (1981), Nachwort. Gesetzesbegirff und Gesetzesvorbehalt. Bemerkungen zur Entwicklung und zum heutigen Stand der Diskussion, w: Gesetz und gesetzgebende Gewalt. Von den Anfängen der deutschen Staatsrechtslehre bis zur Höhe des staatsrechtlichen Positivismus, Berlin.

Britz G. (2015), Das Verhältnis von Verfassungsgerichtsbarkeit und Gesetzgebung, „Juristische Ausbildung, nr 4, s. 319-325. 
Bundesverfassungsgericht Statistiken, http://www.bundesverfassungsgericht.de/DE/Verfahren/Jahresstatistiken/2015/gb2015/A-IV-1.pdf?_blob=publicationFile\&v=1.

Derlatka M. (2009), Skarga Konstytucyjna w Niemczech, Wydawnictwo Sejmowe, Warszawa.

Dynamika liczby spraw w Trybunale Konstytucyjnym w latach 1998-2014, https://trybunal.gov.pl/fileadmin/content/dokumenty/ds.pdf.

Garlicki L. (1990), Vier Jahre der Verfassungsgerichtsbarkeit in Polen, „Jahrbuch des öffentlichen Rechts", s. 285-317.

Izdebski H. (2016), Konstytucjonalizm - legicentryzm - ustawowy nihilizm prawny. O powołaniu naszych czasów do nauki konstytucji, „Państwo i Prawo”, nr 6, s. 5-24.

Jestaedt M., Lepsius O., Möllers Ch., Schönberger Ch. (2011), Das entgrenzte Gericht, Eine kritische Bilanz nach sechzig Jahren bundesverfassungsgericht, Edition Surkamp, Berlin.

Kingreen T., Poscher R. (2016), Grundrechte, Staatsrecht II, Monachium.

Lepsius O. (2015), Entscheiden durch Maßstabbildung, w: R. C. van Ooyen, M. H. W. Möllers, Handbuch Bundesverfassungsgericht im politischen System, Springer, Wiesbaden.

Łętowska E. (1992), Pomóż sam sobie, w: Jak zaczynat Rzecznik Praw Obywatelskich, s. 5-8, Łódź.

Łętowska E. (2012), Rzeźbienie państwa prawa 20 lat później, E. Łętowska w rozmowie z Krzysztofem Sobczakiem, LEX, Warszawa.

Małajny R. M. (2013), Polskie prawo konstytucyjne na tle porównawczym, C.H. Beck, Warszawa.

Mączyński A. (2006), Orzeczenia Trybunału Konstytucyjnego, w: Ksiega XX-lecia orzecznictwa Trybunału Konstytucyjnego, red. M. Zubik, Wydawnictwo Trybunału Konstytucyjnego, Warszawa.

Radbruch G. (1946), Gesetzliches Unrecht und übergesetzliches Recht, w: Süddeutsche Juristenzeitung, s. 105-108.

Rozmaryn S. (1948), Kontrola konstytucyjności ustaw, „Państwo i Prawo”, nr 12, s. 20 i n.

Sulikowski A. (2016), Trybunat Konstytucyjny a polityczność. O konsekwencjach upadku pewnego mitu, „Państwo i Prawo”, nr 1, s. 3-14.

Werner F. (1959), Verfassungsrecht als konkretisiertes Verwaltungsrecht, w: Deutsches Verwaltungsblatt, s. 527-533.

\section{Akty prawne i orzecznictwo:}

Grundgesetz für die Bundesrepublik Deutschland (GG) BGBl. z 1949, s. 1 z późn. zm.

Bundesverfassungsgerichtsgesetz (BVerfGG), BGB1. I z 1993, s. 1473.

Konstytucja Rzeczypospolitej Polskiej z dnia 2 kwietnia 1997 r., Dz. U. 1997, Nr 78, poz. 483.

Ustawa o Trybunale Konstytucyjnym z dnia 1 sierpnia 1997 r., Dz. U. 1997, Nr 102, poz. 643 z późn. $\mathrm{zm}$.

Ustawa o Trybunale Konstytucyjnym z dnia 22 lipca 2016 r., Dz. U. 2016, poz. 1157.

Entscheidungen des Bundesverfassungsgerichts, tom 7, str. $14 \mathrm{i} \mathrm{n.}$

Wyrok Trybunału Konstytucyjnego z dn. 15.10.2002 r. (sygn.: SK 6/02).

\section{Individual Constitutional Complaints in Poland and Germany. How do Procedural Differences Affect the Position of the Courts?}

\section{Summary}

The tendency to compare the Polish Constitutional Court with its German counterpart produces an illusion that the two institutions not only enjoy almost identical positions in their respective countries, but also that they follow the same procedures and have almost identical powers of adjudication, making 
the actual position of both institutions similar. The paper deals with the differences in proceedings on constitutional complaints in Poland and Germany and their importance for the actual position of the two courts. The narrow model of constitutional complaint in Poland after 1997 (in particular the possibility to complain solely 'about the regulation' and not any about any action of the state) has given a relatively narrow range of ruling to the Polish court from the very beginning. In contrast, due to the extensive access German citizens have to constitutional complaints, its German counterpart issues a wide range of verdicts in different fields of life, and their power resembles that of precedents in Anglo-Saxon law. Thus, one reason for the relatively minor importance of the Constitutional Court in Poland is the limited access of citizens to lodge constitutional complaints, which results in a smaller number of verdicts, making it impossible to develop such a wide range of verdicts as is the case in Germany. After all, the significance of the court depends, inter alia, on the number of verdicts issued, which equates to the number of matters regulated by its rulings.

Key words: Constitutional Court, Federal Constitutional Court, Constitutional complaint, proceedings before the constitutional court, Constitutional law in Germany 
